\title{
Developing Whiteboard Animation Video Through Local Wisdom on Work and Energy Materials as Physics Learning Solutions During the Covid-19 Pandemic
}

\author{
Azalia Isma Anggraini $^{1 *}$, Warsono ${ }^{2}$, Husnatul Hamidiyah ${ }^{1}$, Surya Jatmika $^{1}$ \\ ${ }^{1}$ Master of Physics Education, Faculty of Mathematics and Natural Sciences, Universitas Negeri Yogyakarta, \\ Indonesia \\ ${ }^{2}$ Department of Physics Education, Faculty of Mathematics and Natural Sciences, Universitas Negeri Yogyakarta, \\ Indonesia \\ "Corresponding author. Email: azaliaisma.2019@student.uny.ac.id
}

\begin{abstract}
The purpose of this study are (1) to produce whiteboard animation video through local wisdom on work and energy materials as a physics learning solution during the Covid-19 pandemic (2) to test the feasibility of whiteboard animation video through local wisdom on work and energy materials as a physics learning solution during the Covid-19 pandemic. The development procedure use in this research was 4D model which consisted of define, design, develop, and disseminate. Validation and assessment process were are carried out by material and media experts. The results of this study was (1) a product in the form of whiteboard animation video through local wisdom on work and energy materials as a physics learning solution during the Covid-19 pandemic. (2) whiteboard animation video that has been developed has a high feasibility score. Then, whiteboard animation video through local wisdom on work and energy materials is feasible to be used as physics learning solution during Covid-19 pandemic.
\end{abstract}

Keywords: Whiteboard animation video, Local wisdom, Work and energy, Physics learning, Covid-19 pandemic

\section{INTRODUCTION}

The digital world in the Industrial Revolution 4.0 era has been used in various aspects, one of which is education [1]. In the educational aspect requires media or tools to support learning. Students and educators have used digital products, namely multimedia in the learning process [2]. It is supported technological developments that can be easily accessed. So that students are more interested and happy to learn through multimedia or technology-based media [3]. Students always use technology, so using multimedia as a tool for delivering learning concepts will be very useful. Mixing and matching the development of communication and information technology with learning is the right thing [4]. Multimedia learning makes students learn independently [2]. Furthermore, multimedia visualizes a concept clearly and attractively, so that students can easily learn independently.

Moreover, learning in the 2020/2021 school year cannot be implemented directly in schools, because of the coronavirus disease (Covid-19) [5]. This changes in the learning process at school. In order to prevent the transmission of the Covid-19 virus, according to the policy of the government of the Republic of Indonesia, independent learning was implemented [6]. Students learn independently in their homes and they are directed by the school. Educators guided students in online class, using the applications such as WhatsApp group, zoom and other [7]. The mentioned applications make students and educators easier to do their learning process virtually. Learning with virtual 
or online is an effective solution for learning [8][9]. As a result, during this pandemic the use of technology has increased significantly, especially for online learning [10]. Even though learning has been carried out online, it would be better if educators use the media as a tool to make it easier for educators to convey material. Technology can be used to create a medium that educators can use in delivering material [11][12]. One of the digital technology products that can be used to create a learning medium is a whiteboard animation video [13]. Whiteboard animation videos can pack and visualize the material in a clear and attractive manner. This multimedia video format with a background of white (like a blackboard) which is animated [14]. Learning by using video can provide independent learning solutions because it is not obstructed by distance and time [15]. Whiteboard animation videos can be used as a means of conveying the material [16]. Animation in a video can visualize the application or depiction of a material.

In school, there are several subjects or material delivered by educators. Various materials about knowledge taught in schools, one of them is physics [17]. Physics material is taught in schools, but some students experience a higher level of difficulty in learning the concept [18]. Students have difficulty learning physics material because they do not understand the concepts and problem solving in physics. And because physics material consists of many concepts, equations and principles [19]. In order to make physics learning as a less difficult lesson according to students, it needs to be designed so that when learning physics students are interested in learning to understand physics material [17] [20]. One of them is by making physics material packaged clearly, attractively, and presenting real application examples. The solution can be by visualizing physics material in daily activities [21].

Activities in daily life are clearly related to physics, including activities that have local wisdom values [22]. In Indonesia, there are various kinds of tribes, customs and others, so that there are various kinds of local wisdom in each region. Students today may not know the local wisdom that exists in their area. Today's generation of students hardly recognize activities with local wisdom, even though local wisdom has values that can build civilization in society [23][24]. Local wisdom has positive meanings and values that can be used by students. Students need to know and apply the values of the diversity of Indonesian local wisdom. In order for students to know local wisdom, learning can be designed by collaborating knowledge with local wisdom. One of the knowledge that can be collaborated with local wisdom is physics. Because in local wisdom contains activities which are the application of physics material. Local wisdom can potentially be a learning resource that is integrated with physics learning [25][26].

This paper discusses the results of a learning innovation as a physics learning solution during the Covid-19 pandemic. Learning innovation in the form of learning multimedia development, namely a whiteboard animation video through local wisdom on work and energy materials as a physics learning solution during the Covid-19 pandemic.

\section{RESEARCH METHOD}

This was research is a research and development (R\&D) which refers to 4D model. According to Thiagarajan [27], this model consists of four steps, namely define, design, develop, and disseminate.

\subsection{Research Procedure}

The procedures of this development include: a) define, b) design, c) develop and d) disseminate. This research was conducted at MAN 2 Yogyakarta on physics subjects in class X MIPA 2. Work and energy materials was packaged in a whiteboard animation video, which was included concept, equation, work and energy applications on state the name of the local wisdom. Before the video was made, defining process was carried out such as defining the concepts, equations, and also work and energy applications. Referring to the 2013 curriculum effort and energy material. The concepts are guided by the physics book for Class X Senior High School.

The second stage was design, at this stage the content of the video will be designed into story boards and made it detail scene by scene. The next stage is developing. At this stage, the research used some software to make the video namely Adobe Animated CC 2018 to create animation, CorelDraw X8 to create images in the form of graphics and equations, Sparkol VideoScribe to create video whiteboard animation and Filmora9 to edit video visuals combined with audio. 
The developed video was needed to validate in order to find out whether the product is feasible or not to be used as learning resource. Validation will be carried out by media and material experts. The instrument used was a validation sheet which contained media and material aspects. At the dissemination stage, the developed video will be uploaded to the WhatsApp group for class X MIPA 2 MAN 2 Yogyakarta.

\subsection{Data Analysis Techniques}

The data obtained from media and material experts was quantitatively analyzed by calculating the score of all aspects. The average score level is calculated using the following equation:

$$
\overline{\mathrm{X}}=\frac{\sum \mathrm{X}}{\mathrm{n}}
$$

With, $\bar{X}$ is average score rating, $\sum X$ is total score of each component and $n$ is number of validators.

The average obtained is converted to four scales with the following steps:

1. Find the ideal mean $\left(\bar{X}_{l}\right)$ with equation:

$\bar{X}_{\mathrm{l}}=\frac{1}{2}\left(\mathrm{X}_{\max }+\mathrm{X}_{\min }\right)$

Then find the ideal standard deviation (SBi) with the following equation:

$$
\mathrm{SBi}=\frac{1}{6}\left(\mathrm{X}_{\max }-\mathrm{X}_{\min }\right)
$$

2. Converting scores into values with criteria according as in Table 1 below:

Table 1. Assessment criteria using scale four

\begin{tabular}{|c|c|}
\hline Intervals & Category \\
\hline$\overline{\mathrm{X}}_{I}+1,8 \mathrm{SBx}<\overline{\mathrm{X}}$ & Very Good \\
\hline$\overline{\mathrm{X}}_{I}+0,6 \mathrm{SBx}<\overline{\mathrm{X}} \leq \overline{\mathrm{X}}_{I}+1,8 \mathrm{SBx}$ & Good \\
\hline$\overline{\mathrm{X}}_{I}-0,6 \mathrm{SBx}<\overline{\mathrm{X}} \leq \overline{\mathrm{X}}_{I}+0,6 \mathrm{SBx}$ & Enough \\
\hline$\overline{\mathrm{X}}_{I}-1,8 \mathrm{SBx}<\overline{\mathrm{X}} \leq \overline{\mathrm{X}}_{I}-0,6 \mathrm{SBx}$ & Less \\
\hline$\overline{\mathrm{X}} \leq \overline{\mathrm{X}}_{I}-1,8 \mathrm{SBx}$ & Very Poor \\
\hline
\end{tabular}

\section{RESULTS AND DISCUSSION}

\subsection{Results}

This learning multimedia was developed based on observations of student's characteristics. There are still students who have difficulty understanding the concepts of physics and applying equations to solving problems. Furthermore, the learning patterns of students have been changed into online learning due to the Covid-19 pandemic. In addition, the use of whiteboard animation videos as a learning resource, coupled with the application of local wisdom activities in physics material is still limited.

Whiteboard animation video was developed using software Adobe Animated CC 2018, CorelDraw X8, Sparkol VideoScribe, and Filmora9. Work and energy materials are presented based on the physics book for class $\mathrm{X}$. The video was made based on physics book and storyboard which explained about (1) work, (2) kinetic energy (3) potential and mechanical energy. Multimedia learning that has been made really helps students learn independently, because students can study anywhere and anytime. Whiteboard animation videos can be easily sent using Whatsapp application, because currently online learning is carried out with the help of this application. Students only need to download the file of whiteboard animation video in moving picture 4 (.mp4) format which has been sent to the WhatsApp group. Whiteboard animation videos can be easily played on a smartphone or laptop. Here are some scenes from the whiteboard animation videos that have been developed:
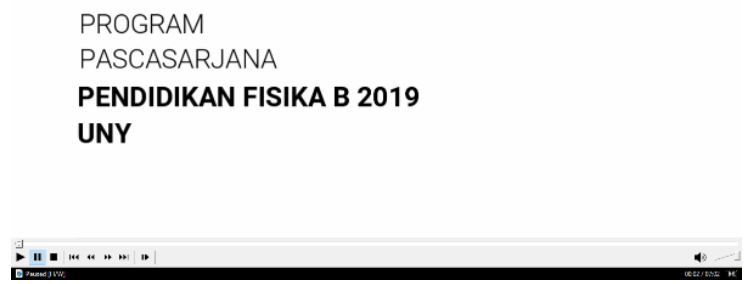

Figure 1 Scene 1 view of the entire video 


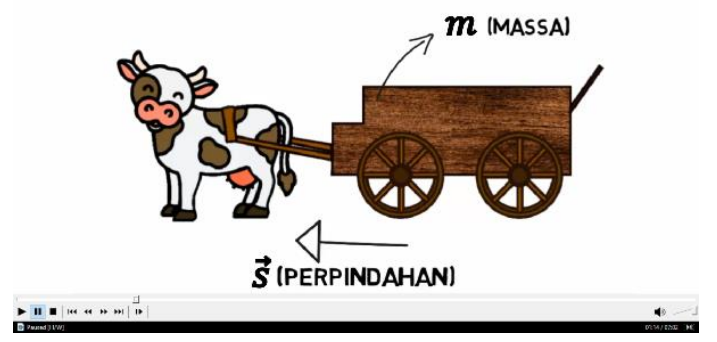

Figure 2 Video display 1 scene 4

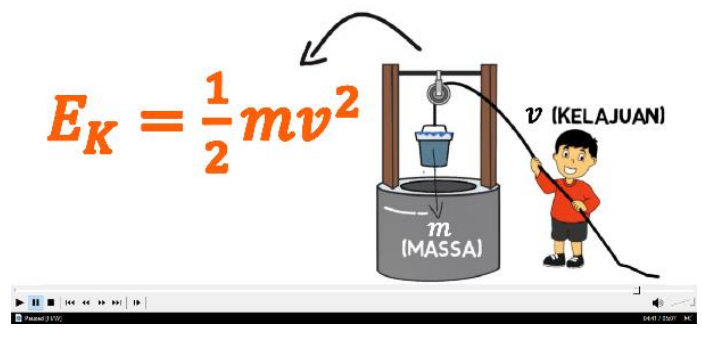

Figure 3 Video display 2 scene 14

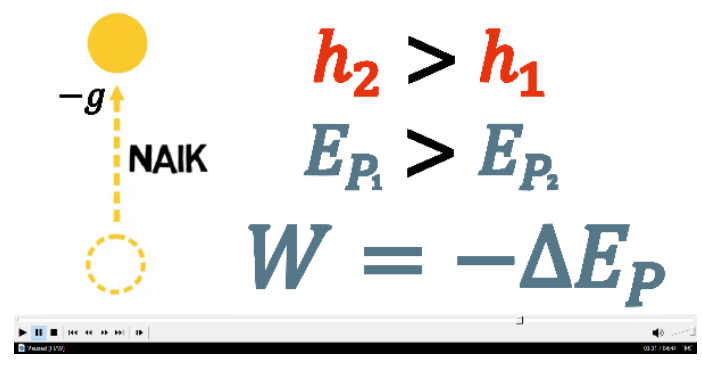

Figure 4 Video display 3 scene 10

In the three videos, the first scene contains the identity of the video developer, so the entire initial scene as in Figure 1 is uniform. For the following scenes, all videos contain work and energy materials that are integrated with local wisdom. The work material is shown in Figure 2, the kinetic energy material is shown in Figure 3 and the potential and mechanical energy material is shown in Figure 4. Each video has a different duration, because the explanation of the material presented by each video is different. The duration of first video is 7 minutes and 1 second, second video is 5 minutes and 6 second, third video is 4 minutes and 44 second. Visualization of text, images and animation of work and energy concepts integrated with local wisdom was simply made in its presentation.
The first video explanation is about work material, the second scene is presented with animation, namely local wisdom activities. The local wisdom in this video is a moving cow carrying a load of grass. The application of local wisdom is presented in the initial scene, so that students can immediately know the application of work materials in everyday life. The following scenes discuss the concepts and mathematical equations of work material. Text, image, animation and audio explanations have also been aided. The last scene of the work material was presented with examples of questions and their solutions. Examples of questions and their solutions are presented in order to provide an overview to students in solving work material problems.

The second video explained is about kinetic energy material, the second scene was presented with local wisdom activities, namely a child who was drawing up the water from a well. The application of local wisdom presented was the application of energy kinetic material in everyday life. The next scenes discuss the concepts and mathematical equations of the kinetic energy matter. This video also discussed how the general equation for kinetic energy was obtained.

Explanation of the third video about potential energy and mechanical matter. The local wisdom application presented was the same as the second video. Energy material is related to work material so that in the initial scene an explanation is presented regarding the relationship between the two materials. The scenes then discuss the concepts, equations and applications of potential energy material. This video also provides a graph of the relationship between effort and potential energy. After discussing potential energy, the next scene discusses mechanical energy. Scene on mechanical energy material discusses its mathematical concepts and equations.

The three videos that have been developed are then validated. This is to find out whether the product being developed was feasible or not to be used as a source of learning physics during the Covid-19 pandemic. Validation was carried out by media and material experts. The validation results of the media experts are shown in Table 2. 
Table 2. The validation results of media experts

\begin{tabular}{|c|c|c|c|}
\hline Aspect & Interval & $\begin{array}{c}\text { Average } \\
\bar{X})\end{array}$ & Category \\
\hline $\begin{array}{c}\text { Language, } \\
\text { Layout, } \\
\text { Visualization, } \\
\text { Typography, } \\
\text { Narration, } \\
\text { Audio }\end{array}$ & $6,39<\bar{X}$ & 8 & Very \\
good
\end{tabular}

Total score of media validation results given by the validator is then compared with the categorization in Table 1 to determine whether the media that has been developed is categorized good or not. Based on the results of the media validation score analysis, it was obtained a mean of 8 . According to the interval in Table 2 which states if the mean is greater than 6.39 then it is included in the very good category.

The analysis result of the material validation scores obtained from material experts are shown in Table 3.

Table 3. The validation results of material experts

\begin{tabular}{|c|c|c|c|}
\hline Aspect & Interval & $\begin{array}{c}\text { Average } \\
\overline{(\bar{X}})\end{array}$ & Category \\
\hline $\begin{array}{c}\text { In accordance } \\
\text { with the } \\
\text { Indicators, } \\
\text { Learning } \\
\text { Objectives, Work } \\
\text { \& Energy } \\
\text { Concepts }\end{array}$ & $6,39<\bar{X}$ & 8 & Very \\
good
\end{tabular}

Based on the results of the material validation score analysis, a mean of 8 . In accordance with the interval in Table 3 which states if the mean is greater than 6.39 then it is included in the very good category.

The average score of the validation results from the media and material experts obtained was 8 from a range of 0 to 8 . Thus, the results of the media and material validation were included in the very good category and suitable for use. So that the whiteboard animation video of integrated work material and energy of local wisdom is suitable for use as a source of learning physics.

\subsection{Discussion}

Whiteboard animation video through local wisdom developed is included in the very good category and is suitable for use in learning physics. The integration of local wisdom into physics material can make learning more interesting and meaningful. This is the same as the results of previous studies which state that physics learning that is integrated with local wisdom can make physics learning interesting and has its own meaning [24]. Because students can find out activities from local wisdom related to physics [23].

Multimedia learning is developed has the visualization of text, images and interesting animation. It is also flexible and practical to use because the whiteboard animation video of work and energy materials can be easily used for independent study during the Covid-19 pandemic. This multimedia can be easily accessed with the help of a digital platform. Learning with the help of online platforms can make it easier to access information [28]. If there is physics material that has not been understood, students can easily play back the learning video. In accordance with the results of previous research that using multimedia whiteboard animation, videos physics learning become more varied and interesting. So that students will be more happy and interested in learning physics [13]. Moreover, it is easy to operate, videos can be played using technology products, namely smartphones or laptops [3].

\section{CONCLUSION}

A whiteboard animation video through local wisdom on work and energy materials as a physics learning solution during the Covid-19 pandemic has been developed. The product that has been developed has resulted in three physics learning videos. The first video is about work material, the second video is about kinetic energy and the third video is about potential energy and mechanical energy. Based on media experts and material experts, the three products that have been developed are in the very good category. Then the three products are suitable for use as a source of learning physics during the COVID-19 pandemic.

\section{REFERENCES}

[1] K. Umachandran, I. Jurcic, D.F. James, M.M.T Said, A.A. Rashid, Gearing Up Education Towards Industry 4.0, Journal International 
Journal of Computers \& Technology 17(2) (2018) 7305-7312. DOI: https://doi.org/10.24297/ijct.v17i2.7754

[2] D.A. Muller, Designing Effective Multimedia for Physics Education School of Physics University of Sydney Australia, 2008.

[3] A.A. Saputri, I. Wilujeng, Developing Physics EScaffolding Teaching Media to Increase the Eleventh-Grade Students Problem Solving Ability and Scientific Attitude International, Journal of Environmental \& Science Education 12(4) (2017) 729-745.

[4] K.D. Su, S.C. Yeh, Effective Assessments of Integrated Animations - Exploring Dynamic Physics Instruction for College Students' Learning and Attitudes The Turkish Online, Journal of Educational Technology 176 (2015) 588-595.

DOI:

https://doi.org/10.1016/j.sbspro.2015.01.514

[5] W. Bao, Covid-19 and Online Teaching in Higher Education: A Case Study of Peking University, Human Behavior and Emerging Technologies WILEY 2 (2020) 113-115. DOI: https://doi.org/10.1002/hbe2.191

[6] Kementerian Pendidikan dan Kebudayaan, Kementerian Agama, Kementerian Kesehatan, dan Kementerian dalam Negeri 2020 Panduan Penyelenggaraan Pembelajaran Pada Tahun Ajaran 2020/2021 dan Tahun Akademik 2020/2021 di Masa Pandemi Coronavirus Disease (Covid-19), Accessed on: Oct. 2020, [Online]. Available: https://covid19.go.id/storage/app/media/Materi \%20Edukasi/Buku_Panduan_Pembelajaran_Ma sa_Pandemi_A5_2020.pdf

[7] J.W. Kusuma, Hamidah, Perbandingan Hasil Belajar Matematikan dengan Penggunaan Platform Whatsapp Group dan Webinar Zoom dalam Pembelajaran Jarak Jauh Pada Masa Pandemik Covid-19, Jurnal Ilmiah Pendidikan Matematika 5(1) (2020) 97-106. DOI: http://dx.doi.org/10.26877/jipmat.v5i1.5942

[8] L.D. Herliandry, Nurhasanah, M.E. Suban, H. Kuswanto, Pembelajaran Pada Masa Pandemi Covid-19 Jurnal Teknologi Pendidikan 22(1) (2020) 65-70. DOI: https://doi.org/10.21009/jtp.v22i1.15286
[9] Z. Abidin, Rumansyah, K. Arizona, Pembelajaran Online Berbasis Proyek Salah Satu Solusi Kegiatan Belajar Mengajar Di Tengah Pandemi Covid-19, Jurnal Ilmiah Profesi Pendidikan 5(1) (2020) 64-70. DOI: https://doi.org/10.29303/jipp.v5i1.111

[10] K. Goldschmidt, The Covid-19 Pandemic: Technology Use to Support The Wellbeing of Children, Journal of Pediatric Nursing 53 (2020) 88-90.

DOI: https://doi.org/10.1016/j.pedn.2020.04.013

[11] H. Suh, Collaborative Learning Models and Support Technologies in The Future Classroom International, Journal for Educational Media and Technology 5(1) (2011) 50-61. DOI:

[12] J. Jaldemark, S. Hrastinski, A.D. Olofsson, L.M. Oberg, Editorial Introduction: Collaborative Learning Enhanced by Mobile Technologies, British Journal of Educational Technology 49(2) (2018) 201-206. DOI: https://doi.org/10.1111/bjet.12596

[13] S. Turkay, The Effect of Whiteboard Animations on Retentation and Subjective Experiences When Learning Advanced Physics Topics, Journal Computers \& Education, Elsevier 98 (2016) 102-114. DOI: https://doi.org/10.1016/j.compedu.2016.03.004

[14] J. Air, E. Oakland, C. Walters, How To Design Your Own Whiteboard Animation Video Bristol, UK : Sparkol Books, 2015.

[15] R.E. Mayer, Multimedia Learning, Cambridge University Press, 2009.

[16] M. Li, C.W. Lai, W.M. Szeto, Whiteboard animation for flipped classroom in a common core science general education course, International Conference on Higher Education Advance, Universitat Polit'ecnica de Val'encia, Val'encia, 2019, pp. 929-938. DOI: http://dx.doi.org/10.4995/HEAd19.2019.9250

[17] Y. Yelensi, K. Wiyono, N. Andriani, Efektivitas Penggunaan Video Pembelajaran Materi Usaha dan Energi Berbasis Permainan Tradisional, Jurnal Pijar MIPA 15(1) (2020). DOI: http://dx.doi.org/10.29303/jpm.v15i1.1119

[18] F. Haroky, S. Nikmah, I. Wilujeng, Jumadi, H. Kuswanto, Android assisted physics comic 
learning to train students'conceptual understanding of newton's gravity, in: Journal of Physics: Conference Series, IOP Publishing, Bristol, 2019, pp. 1-10. DOI: https://doi.org/10.1088/1742$\underline{6596 / 1233 / 1 / 012045}$

[19] J. Purwanto, Winarti, Profil Pembelajaran Fisika dan Kemampuan Berpikir Kritis Siswa Madrasah Aliyah se-DIY, Jurnal Penelitian Pembelajaran Fisika 7 (2016) 8-18. DOI: http://dx.doi.org/10.26877/jp2f.v7i1.1148

[20] K. Wiyono, Pengembangan Model Pembelajaran Fisika Berbasis ICT Pada Implementasi Kurikulum 2013, Jurnal Inovasi dan Pembelajaran Fisika 2(2) (2015) 123-131. DOI: https://doi.org/10.36706/jipf.v2i2.2613

[21] A.P.A Rino, Y. Ruhiyat, F.C. Wibowo, Pengembangan Media Physics Game Learning pada Konsep Perubahan Wujud Zat, UNNES Physics Education Jurnal 8(1) (2019) 60-65. DOI: https://doi.org/10.15294/upej.v8i1.29514

[22] C. Rochman, D. Nasrudin, R. Rokayah, N.Hermita, A. Malik, I. Suhada, Integration of local wisdom in science learning, in:Proceedings of the 2nd Asian Education Symposium (AES), Atlantis Press, France, 2018, pp. 424-428. DOI: http://dx.doi.org/10.5220/0007305504240428

[23] A. Rusilowati, Supriyadi, A. Widiyatmoko, Pembelajaran Kebencanaan Alam Bervisi SETS Terintegrasi dalam Mata Pelajaran Fisika Berbasis Kearifan Lokal, Jurnal Pendidikan Fisika Indonesia 11(1) (2015) 42-48. DOI: https://doi.org/10.15294/jpfi.v11i1.4002

[24] T.E. Anggraeni, Mundilarto, The Development of Local Wisdom-Based Physics Cognitive Ability Assesmnet Instrument for Senior High School Students, Jurnal Penelitian dan Pembelajaran IPA 6(1) (2020) 102-140. DOI: http://dx.doi.org/10.30870/jppi.v6i1.5718

[25] P.W. Hastuti, W. Setianingsih, P. Anjasari, How to develop students scientific literacy through integration of local wisdom in yogyakarta on science learning, in: Journal of Physics: Conference Series, IOP Publishing, Bristol, 2020, pp.1-7. DOI: http://dx.doi.org/10.1088/1742$\underline{6596 / 1440 / 1 / 012108}$
[26] Usmeldi, R. Amini, The effect of integrated science learning based on local wisdom to increase the students competency, in: Journal of Physics: Conference Series, IOP Publishing, Bristol, 2020, pp.1-7. DOI: http://dx.doi.org/10.1088/1742$\underline{6596 / 1470 / 1 / 012028}$

[27] S. Thiagarajan, D.S. Semmel, M.I. Semmel, Instructional Development for Training Teachers of Expectional Children. Minneapolis Minnesota: Leadership Training Institute/Special Education, University of Minnesotanderson, 1974.

[28] D.W Anderson, V.D Vault, C.E. Dickson, Problems and Prospects for the Decades Ahead: Competency Based Teacher Education, McCutchan Publishing Co, 1999.

[29] B. Setiaji, P.A.C. Dinata, Analisis Kesiapan Mahasiswa Jurusan Pendidikan Fisika Menggunakan E-Learning dalam Situasi Pandemi Covid-19, Jurnal Inovasi Pendidikan IPA 6(1) (2020) 59-70. DOI: https://doi.org/10.21831/jipi.v6i1.31562 